\title{
Absence of Modifications of the Enzyme Defense System against Oxygen Toxicity in Cystic Fibrosis
}

\author{
F. CARMAGNOL, (20) P.M. SINET, G. LENOIR, A. NICOLE, J. RAPIN, AND H. JÉROME \\ Laboratoire de Biochimie Génétique, Hôpital Necker-Enfants Malades, Paris, France
}

\begin{abstract}
Summary
Cystic fibrosis (CF) has recently been linked to the group of human diseases in which cultured fibroblasts express premature aging. As the deleterious effect of oxygen derivatives in the cell is one of the numerous pathways associated with cell aging, the activity of the enzymatic defense system, superoxide dismutase (SOD), glutathione peroxidase (GSHPx), glutathione reductase (GR), was examined in the erythrocytes of $12 \mathrm{CF}$ children and was compared to age-matched normal controls. No significant differences were found in CF children when compared to the controls. Glutathione$\mathrm{S}$-transferase was also assayed, but the significant difference found between CF children and normal controls is probably not specific of $\mathrm{CF}$ as it is found in other pathologic situations such as hyperbilirubinemia or renal insufficiency.
\end{abstract}

\section{Abbreviations}

CF, cystic fibrosis

FAD, flavin adenine dinucleotide

GR, glutathione reductase

GSHPx, glutathione peroxidase

GST, glutathione-S-transferase

SOD, superoxide dismutase

Cystic fibrosis $(\mathrm{CF})$ is a lethal exocrinopathy transmitted as an autosomal recessive condition, in which the abnormal gene defect remains unknown despite numerous studies (5). It has been reported that CF was part of that group of human diseases in which cultured fibroblasts express premature aging (15). It has also been reported that CF red blood cells were, in terms of NADP, in a more oxidized state than normal red blood cells (13), this being related to an increased activity of the pentose phosphate pathway. Cellular aging is held to be associated with the deleterious effect of free radicals, which arise through oxidation reactions and lipid peroxide formation, that can damage cell constituents (8). Among the oxygen derivatives encountered within cells are the superoxide anion, $\mathrm{O}_{2}{ }^{-}$, hydrogen peroxide $\mathrm{H}_{2} \mathrm{O}_{2}$, and the hydroxyl radical $\mathrm{OH}$. As these intermediates are too reactive to be well tolerated, they are catalytically scavenged by enzymes that provide a primary defense system (6). $\mathrm{O}_{2}{ }^{-}$is eliminated by the superoxide dismutase (SOD) (E.C.1.15.1.1.), $\mathrm{H}_{2} \mathrm{O}_{2}$ by glutathione peroxidase (GSHPx) (E.C.1.11.1.9) and by catalase (E.C.1.11.1.6.). It seemed therefore important to measure the activities of these enzymes, in order to determine a possible role of accelerated oxidative processes in the pathogeny of the disease. Glutathione reductase (GR) (E.C.1.6.4.2.) was also measured as it provides the GSHPx with the necessary reduced glutathione (GSH). Glutathione-S-transferase (GST) (E.C.2.5.1.18.), an enzyme engaged in the detoxification of both endogenous and exogenous compounds (10), was measured as it functions by catalyzing their conjugation with GSH.

Copper-zinc SOD, GSHPx, catalase, glutathione reductase (GR), and GST were measured in the erythrocytes of twelve CF children and 24 normal control children.

\section{MATERIALS AND METHODS}

Three ml veinous blood were collected with heparin (62 Units per $5 \mathrm{ml}$ of whole blood) and immediately centrifuged $(15 \mathrm{~min}$, $500 \times g$ ). Plasma and buffy coat were then removed and erythrocytes were washed twice in $0.15 \mathrm{M} \mathrm{NaCl}$. The washed erythrocytes were then stored at $-70^{\circ} \mathrm{C}$ until assay.

All spectrophotometric determinations were performed in a Gilford recording spectrophotometer, model 240: GSHPx and GR at $37^{\circ} \mathrm{C}$ and SOD and GST at $25^{\circ} \mathrm{C}$. SOD activity was measured in a reaction system containing riboflavin and nitroblue tetrazolium (11), with the following modification: before being eliminated by an ethanol-chloroform precipitation, hemoglobin is adjusted to $8 \%$ in the hemolysate (16). In this system, one unit corresponds to $0.5 \mu \mathrm{g}$ of human copper-zinc SOD purified according to Hartz and Deutsch (9). GSHPx was measured by a coupled enzyme procedure with glutathione reductase and NADPH using ter-butyl hydroperoxide as substrate (17). Hemoglobin was adjusted to $2.5 \%$ in the hemolysate and then converted to cyanmethemoglobin by potassium cyanide and potassium ferricyanide, in order to minimize its pseudoperoxidase activity. One unit of GSHPx was taken as the amount of enzyme that transformed $1 \mu$ mole of NADPH under the assay conditions. Glutathione reductase was assayed according to Beutler (1), with and without the addition of exogenous FAD. One unit of enzyme activity was taken to be the amount of enzyme that transformed $1 \mu$ mole of NADPH per min under the assay conditions. Glutathione-S-transferase was assayed with 1-chloro-2,4-dinitrobenzene and GSH as substrates. The formation of the S-conjugate was monitored by following its absorbance at $340 \mathrm{~nm}$ (2). One unit of enzyme activity is defined as the amount of enzyme which catalyses the formation of $1 \mu$ mole of S-conjugate per min under the assay conditions. Catalase was assayed according to Cohen et al. (4). Results are expressed in units of catalase per $g$ of hemoglobin.

\section{RESULTS AND DISCUSSION}

Results are given in Table 1. It has been reported recently (7) that there is a significant increase of the activities of the red cell copper-zinc SOD and catalase in $\mathrm{CF}$, which led the authors to hypothesize the presence of a genetically determined alteration in the formation and catabolism of the lipid formation products. No such increase was found by us in CF children as compared to healthy children. The slight but not significant increase in copperzinc SOD activity that we find in CF children is not comparable to the 2 -fold increase found by Gyurkovits et al. (7).

GSHPx is found to be slightly but not significantly decreased in CF children compared to controls, which is similar to the data given by Castillo et al. (3) and Llyod-Still and Ganther (12). Gyurkovits et al. (7) also mentioned normal values for GSHPx in $\mathrm{CF}$. Catalase activity is similar in CF and control children, which differs from the 7 -fold increase found for the erythrocyte catalase activity of CF children.

CF children have similar GR values in comparison with controls, when assayed with and without FAD; the assay of GR 
Table 1. Erythrocytic enzyme levels implicated in the defense against oxygen toxicity in control and cystic fibrosis subjects

\begin{tabular}{|c|c|c|c|}
\hline & Controls & $\begin{array}{l}\text { Cystic } \\
\text { Fibrosis }\end{array}$ & $P$ \\
\hline $\begin{array}{c}\text { Superoxide dismutase } \\
\left(\mu \mathrm{g} \cdot \mathrm{g} \mathrm{Hb}^{-1}\right)\end{array}$ & $\begin{array}{c}704 \pm 55 \\
\quad(71)\end{array}$ & $\begin{array}{c}748 \pm 97 \\
(11)\end{array}$ & N.S. \\
\hline $\begin{array}{l}\text { Glutathione peroxidase } \\
\qquad\left(\mathrm{U} \cdot \mathrm{g} \mathrm{Hb}^{-1}\right)\end{array}$ & $\begin{array}{l}9.28 \pm 3.13 \\
(24)\end{array}$ & $\begin{array}{c}8.11 \pm 4.53 \\
(12)\end{array}$ & N.S. \\
\hline $\begin{array}{l}\text { Catalase }\left(\mathrm{U} \cdot 10^{-3} \cdot \mathrm{g}\right. \\
\left.\mathrm{Hb}^{-\mathrm{I}}\right)\end{array}$ & $\begin{array}{c}11.44 \pm 4.7 \\
(23)\end{array}$ & $\begin{array}{c}14.18 \pm 4.3 \\
(8)\end{array}$ & N.S. \\
\hline $\begin{array}{c}\text { Glutathione-S-transfer- } \\
\text { ase }\left(\mathrm{U} \cdot \mathrm{g} \mathrm{Hb}^{-1}\right)\end{array}$ & $\begin{array}{c}1.65 \pm 0.45 \\
(49)\end{array}$ & $\begin{array}{c}3.14 \pm 0.99 \\
\quad(12)\end{array}$ & $P<0.01$ \\
\hline $\begin{array}{c}\text { Glutathione reductase } \\
\left(\mathrm{U} \cdot \mathrm{g} \mathrm{Hb}^{-1}\right)\end{array}$ & & & \\
\hline $\begin{array}{l}\text { without FAD } \\
\text { with FAD }\end{array}$ & $\begin{array}{c}10.27 \pm 2.12 \\
(24)\end{array}$ & $\begin{array}{c}9.95 \pm 3.28 \\
\quad(11)\end{array}$ & N.S. \\
\hline
\end{tabular}

${ }^{1}$ All assays were done as described in "Materials and Methods." Numbers in parentheses indicate the number of assays. Values for superoxide dismutase and glutathione-S-transferase activities were taken from previous studies done in our laboratory on normal children. Results are expressed as mean \pm S.D.

without the addition of FAD representing the amount of functional enzyme whereas the value obtained with FAD supplementation represents the total amount of enzyme. This is in disagreement with the significantly higher levels of erythrocyte GR activity, assayed without FAD, found by Shapiro et al. (14) in CF subjects.

Significant increases in GST activity are observed in CF children when compared to normal controls. An increase in erythrocyte GST has already been observed in situations where circulating toxic compounds are liable to accumulate, such as renal insufficiency and situations in which blood bilirubin increases (2). As GST is thought to be involved in detoxifying exo- and endogenous compounds, the higher values observed in CF subjects might be ascribed to a compensatory increase in order to deal with circulating toxic compounds rather than to an answer to increased oxidative challenges inside the cell.

As the changes observed in the protective enzyme system against oxygen toxicity are very slight, it is unlikely that $\mathrm{CF}$ erythrocytes are submitted to high oxidative challenges deriving from a genetic defect situated on the metabolism of oxygen derivatives.

\section{REFERENCES AND NOTES}

1. Beutler, E.: Glutathione reductase: stimulation in normal subjects by riboflavin supplementation. Science, 165: 613 (1969).

2. Carmagnol, F., Sinet, P. M., Rapin, J. and Jérome, H.: Glutathione-S-transferase of human red blood cells: Assay, values in normal subjects and in two pathological circumstances: hyperbilirubinemia and impaired renal functions. Clin. Chim. Acta, 117: 209 (1981)

3. Castillo, R., Landon, C., Eckhardt, K., Morris, V., Levander, O. and Leviston, N.: Selenium and vitamin E status in cystic fibrosis. J. Pediatr., 99: 583 (1981).

4. Cohen, G., Dembiec, D. and Marcus, J.: Measurement of catalase activity in tissue extracts. Anal. Biochem., 34: 30 (1970).

5. Di Sant'Agnese, P. A. and Davis, P. B.: Research in cystic fibrosis N. Engl. J. Med., 295: 481 (1976).

6. Fridovich, 1.: The biology of oxygen radicals. Science, 201: 875 (1978).

7. Gyurkovits, K., Szabo, L., Laslo, A., Matkovics, B.: Comparative study of superoxide dismutase, catalase and lipid peroxidation from cystic fibrosis patients. In: F. Falkner, N. Kretchmer and E. Rossi: Monographs in Paediatrics, vol. 14: Current Problems and New Trends in Cystic Fibrosis, p 56 (European Working Group for Cystic Fibrosis, Bern, 1981).

8. Harman, D.: Free radical theory of aging: Effect of free radical reaction inhibitors on the mortality rate of male LAF mice. J. Geront. 23: 476 (1968).

9. Hartz, J. W. and Deutsch, H. F.: Subunit structure of human superoxide dismutase. J. Biol. Chem. 247: 7043 (1972).

10. Jakoby, W. B.: The glutathione-S-transferases: A group of multi-functional detoxification proteins. Adv. Enzymol., 46: 383 (1978).

11. Lavelle, F., Puget, K. and Michelson, A. M.: Superoxyde dismutase. Fonction et concentration de l'érythrocupréine chez l'humain normal. C. R. Acad. Sci. Paris, 278: 2695 (1974)

12. Llyod-Still, J. and Ganther, H. E.: Selenium and Glutathione peroxidase levels in Cystic Fibrosis. Pediatrics, 65: 1010 (1980).

13. Shapiro, B. L., Lee, S. M. and Warwick, W. J.: The pentose phosphate pathway in cystic fibrosis erythrocytes. Biochem. Biophys. Res. Comm., 39: 816 (1970)

14. Shapiro, B. L., Smith, Q. J. and Warwick, W. J.: Red cell glutathione and glutathione reductase in cystic fibrosis. Proc. Soc. Exptl. Biol. Med., 144: 181 (1973).

15. Shapiro, B. L., Louis, L. F., Fast, L. H.: Premature senescence in cultured skin fibroblasts from subjects with Cystic Fibrosis. Science, 203: 1251 (1979).

16. Sinet, P. M., Couturier, J., Dutrillaux, B., Poissonnier, M., Raoul, O., Réthoré M. O., Allard, D., Lejeune, J. and Jérome, H.: Trisomie 21 et superoxyde dismutase-1 (1 PO-A). Tentative de localisation sur la sous-bande 21 q22.1. Exptl. Cell Res., 97: 47 (1975).

17. Sinet, P. M., Michelson, A. M., Bazin, A., Lejeune, J. and Jérome, H.: Increase in glutathione peroxidase activity in erythrocytes from Trisomy 21 subjects. Biochem. Biophys. Res. Commun., 67: 910 (1975).

18. The authors wish to thank Professor P. Kamoun for helpful suggestions and Professor P. Hennequet for giving us some of the CF samples.

19. This work was supported by a grant from the Université René Descartes and by the Centre National de la Recherche Scientifique, ERA 47.

20. Requests for reprints should be addressed to: Dr. F. Carmagnol, Laboratoire de Biochime Génétique, Hôpital Necker-Enfants Malades, Paris, France.

21. Received for publication February 24, 1982.

22. Accepted for publication June 1, 1982. 